\title{
Service Learning in Early Childhood Education: In the Class of Curriculum Design and Practice
}

\author{
Mei-Ling Chuang ${ }^{1}$ \\ ${ }^{1}$ Department of Early Childhood Care and Education, Cheng Shiu University, Kaohsiung City, Taiwan, R.O.C. \\ Correspondence: Mei-Ling Chuang, Department of Early Childhood Care and Education, Cheng Shiu University, \\ No. 840, Chengqing Rd., Niaosong Dist., Kaohsiung City 833, Taiwan (R.O.C.). E-mail: \\ einseinsster@gmail.com
}

Received: November 5, 2018

Accepted: November 30, 2018 Online Published: December 30, 2018

doi:10.5539/jel.v8n1p65

URL: https://doi.org/10.5539/jel.v8n1p65

\begin{abstract}
Qualitative and quantitative research was conducted with undergraduate students majoring in early childhood care and education to explore the impact of service-learning on personal and professional development, as well as to assess satisfaction with the service-learning project. The data were gathered at a baby care center, where these students arranged games, through a questionnaire given to the students $(\mathrm{N}=37)$, a questionnaire given to parents who came with their children to the center $(\mathrm{N}=34)$, as well as reflection paper and report by the students on how they felt about the activity. The qualitative data were analyzed from five different aspects: (1). Enhancing students' academic knowledge and skills, (2). Learning public service from the activity, (3). Cooperation and teamwork, (4) Benefits for children, (5) Suggestions of students afterwards. The findings of this research demonstrated that this service learning experience was beneficial for children, parents and the students, enhancing students' academic knowledge, problem solving skills, as well as interpersonal development.
\end{abstract}

Keywords: service-learning, early childhood, curriculum

\section{Introduction}

The pedagogy on service-learning was boosted in the '70's and early ' 80 's through the work of cognitive psychologists such as Lev Vygotsky and Jerome Bruner. In the 1990's scholars began to conduct research on service-learning as pedagogy (A Brief History of Service-Learning, 2018). During the last two decades, national reform efforts in the US have called on educators to adopt academic service-learning (Lake \& Jones, 2008).

According to the National Service Learning Clearinghouse, service-learning is defined as "a teaching and learning strategy that integrates meaningful community service with instruction and reflection to enrich the learning experience, teach civic responsibility, and strengthen communities" (Bandy, 2017). "Service learning" (also called community engagement pedagogies) combines learning goals and community service in ways that can enhance both students' academic experiences and the needs of communities. It involves experiential learning, connections between classroom content and institute, giving students opportunities to plan, implement, and evaluate the experience; serving the community, and providing opportunities for reflection (Celio et al., 2011). It can benefit students, faculty, academic institutions, community organizations, and community members (Bandy, 2017; Brown \& Schmidt, 2016).

Many studies have pointed out the validity of using out-of-classroom experiences to help students make meaning of rather abstract theories and concepts (A Brief History of Service-Learning, 2018). The positive outcomes from this include stronger problem-solving skills, enhanced personal development (e.g., personal efficacy, personal identity, spiritual growth, and moral development) and interpersonal development (e.g., working well with others and communication skills), increased leadership skills, greater cultural awareness, and tolerance (Eyler et al., 2001). Roofe found that students felt the benefits of service-learning, and they reported that "service-learning should be included in higher education courses as a benefit to them and to the community" (2012, p.32).

In addition, outcome of many studies has found that participation in a service-learning experience has positive influence on academic, personal, social, and citizenship outcomes, with the strongest influence being on academic performance (Conway, Amel, \& Gerwien, 2009). Since service-learning has promoted high-quality learning, federal and state governments are encouraging schools and colleges to promote this strategy (Lake \& 
Jones, 2008).

Several elements are critical for successful service-learning. The National Youth Leadership Council lists K-12 Service-Learning Standards for Quality Practice as elements for successful service-learning (https://nylc.org/standards/):

-Meaningful service

-Reflection: prompting deep thinking and analysis about oneself and one's relationship to society

-Youth voice: provides youth with a strong voice in planning, implementing, and evaluating service-learning experiences with guidance from adults.

-Progress monitoring

-Link to curriculum

-Diversity

-Partnerships

-Duration and intensity

The design of this study was in consistent with most of the elements mentioned in the list.

\section{Service-Learning in Taiwan}

Service learning is becoming increasingly important in Taiwan. Taiwan has started to promote the "service and learning" module in the 1990s and combined it into the curriculum of different subjects (Lin et al., 2013). Since around the year 2000, the government of Taiwan has even paid greater attention to service-learning in higher education. There are different types of service-learning projects in Taiwan. Some are combined with curricula at university. Others are in the form of student-organized groups and student clubs, and go to impoverished or neglected areas of the country during the summer months (Sy, 2011).

\subsection{Service-Learning of Early Childhood Education in Taiwan}

Research about service-learning in early childhood education in Taiwan started around the 2010s. Educators have studied the combination of curricula at university with service-learning. Through reviewing the relevant literature, the researcher found that the numbers of these studies are still seldom, and the courses which combine with service-learning are versatile. Chang (2012) combined a service-learning program with the course "learning environment for young children". In her study, students provided different learning materials for young children at classrooms' corner learning centers in early childhood programs. Chang \& Chen (2014) combined service-learning with two courses: nature science and mathematics, and teaching practicum. They brought 45 college students to plan a nature science program at a zoo for young children and their parents. Chen (2015) applied a service-learning strategy in visual arts in an early childhood education course to guide students to plan parent-child visual arts education courses. Different from the programs above, which combine courses with service-learning, Hsu (2012) combined student's professional knowledge with a service-learning curriculum. She took 30 college students participating in a reading-guidance program in a service-learning curriculum for disadvantaged children in a remote area.

The outcome of the studies above showed that most participants gave positive feedback. The results demonstrate that service-learning enhances students' course learning, benefits students personally, and enhances reciprocal benefits (Chang, 2012; Chang \& Chen, 2014; Chen, 2015). Hsu (2012) showed that most participating college students can generate more positive thinking, and that there is a positive correlation among aspects of students' perspectives toward educational work and both attitudes and future career planning.

\section{Method}

\subsection{Participants}

In the present study, the service learning project included 37 undergraduate students in the department of early childhood care and education. Most of them already had jobs, and studied at university on weekends. Most were working as kindergarten teachers. They attended my course "curriculum design and internship" that semester. The institute cooperating with the service learning project was a baby care center. We designed and led tournament games ('breaking through the barricade'), and the baby care center invited the parents and the siblings of the babies to join the activity. There were 37 undergraduate students and 34 families with young children joining the activity. 


\subsection{Procedures}

The tournament was held on Children's Day in 2017. At the winter vacation in 2017 the institute members and the researcher have already settled down the project and the event date through many times of discussion. At the beginning of the semester the researcher announced the project in classroom and began to prepare for it with the students.

The inside space of the child care center was not very big, but there was a big garden and playground outside. Therefore we planned to use both inside and outdoor space for the activity.

The preparation for the project involved several steps:

1) discussion with institute members about planning of the project;

2) announcement of the project in classroom;

3) teaching theories and training on teaching techniques;

4) group forming and group discussion;

5) designing games, and making lesson plans, teaching materials and posters within groups;

6) doing the project in the child care center;

7) reflection on and evaluation of the project.

The whole class was divided into eight groups. Each group consisted of five to six students. The games of the eight groups were as follows:

1) Love the Earth: Two children have to hold a big balloon with their bodies and then walk together with the balloon from a start line to a finish line.

2) Throw balls for fun: Children have to throw a ball into a box on the ground. If they throw at least 5 balls out of 10 into the box, they win.

3) Bingo: Two children play together to put animal cards on a 9x9 grid. The child who first makes a horizontal, diagonal or vertical line wins.

4) String the straws: Straws are cut in pieces and children have to string the pieces into a bracelet. After finishing, they can take their bracelet home.

5) Fishing: Children pick a colored ball from a box and then have to fish for the same color of bottle and make the bottle stand upright.

6) Guess who I am: Children have to take animal cards to find the animal's silhouette. They have to finish matching animal cards and their silhouette.

7) Sandpaper drawing by using chalk powder: At the beginning chalk power is mixed with salt. Children with the help of their parents put double-sided tape on a piece of sandpaper to make a picture or a pattern. Then children (with the help of their parents) pull away the other side of the double-sided tape. Finally put the chalk powder on the double-sided tape and then a colorful drawing will be finished.

8) Balloon umbrella game: Children and their parents play together with the balloon umbrella.

9) The research was conducted through questionnaires to students and to parents who came with their children to the activity, as well as a reflection paper and a report by the students on how they felt about the activity.

\subsection{Quantitative Data Analysis}

\subsubsection{The Questionnaire for the Undergraduate Students}

Of interest first was the working experience of the undergraduate students in order to analyze the questionnaires they filled out. Among 37 students, $23(62.2 \%)$ were kindergarten teachers at the time, two $(5.4 \%)$ were after-school program teachers, and one $(2.7 \%)$ was a daycare center teacher. Moreover, two $(5.4 \%)$ had been working as a kindergarten teacher or after-school program teacher. Only nine $(24.3 \%)$ had other jobs, which means their jobs are other than working with children. From the data we know that most of the students who joined this service-learning project were experienced teachers of children. 
Table 1. Work experience of the students

\begin{tabular}{ll}
\hline Occupation of the students & $\mathrm{N}=37(\%)$ \\
\hline Working now as kindergarten teacher & $23(62.2 \%)$ \\
Working now as after-school program teacher & $2(5.4 \%)$ \\
Working now as daycare center teacher & $1(2.7 \%)$ \\
Have been working as kindergarten teacher or after-school program teacher & $2(5.4 \%)$ \\
Others & $9(24.3 \%)$ \\
\hline
\end{tabular}

The questionnaire is designed using a Likert scale (with $1=$ strongly disagree, $2=$ disagree, $3=$ neutral, $4=$ agree, and $5=$ strongly agree). The eight questions and results for the students on how they felt about the service learning they had joined are as follows:

Table 2. Student's opinion about the service-learning project

\begin{tabular}{|c|c|c|c|c|c|c|c|}
\hline Question & 1 & 2 & 3 & 4 & 5 & $\mathbf{M}$ & SD \\
\hline $\begin{array}{l}\text { I am satisfied with the content of the service } \\
\text { learning project. }\end{array}$ & $\begin{array}{l}0 \\
(0 \%)\end{array}$ & $\begin{array}{l}0 \\
(0 \%)\end{array}$ & $\begin{array}{l}2 \\
(5.4 \%) \\
\end{array}$ & $\begin{array}{l}17 \\
(45.9 \%) \\
\end{array}$ & $\begin{array}{l}18 \\
(48.6 \%) \\
\end{array}$ & 4.43 & .60 \\
\hline $\begin{array}{l}\text { I feel accomplishment and confidence while } \\
\text { helping others with my profession. }\end{array}$ & $\begin{array}{l}0 \\
(0 \%) \\
\end{array}$ & $\begin{array}{l}0 \\
(0 \%)\end{array}$ & $\begin{array}{l}0 \\
(0 \%) \\
\end{array}$ & $16(43.2 \%)$ & $\begin{array}{l}21 \\
(56.8 \%) \\
\end{array}$ & 4.57 & .50 \\
\hline $\begin{array}{l}\text { This service learning project helped me } \\
\text { increase my professional interest and } \\
\text { motivation for the course. }\end{array}$ & $\begin{array}{l}0 \\
(0 \%)\end{array}$ & $\begin{array}{l}1 \\
(2.7 \%)\end{array}$ & $\begin{array}{l}3 \\
(8.1 \%)\end{array}$ & $\begin{array}{l}14 \\
(37.8 \%)\end{array}$ & $\begin{array}{l}19 \\
(51.4 \%)\end{array}$ & 4.38 & .75 \\
\hline $\begin{array}{l}\text { This project helped me understand the spirit } \\
\text { of cooperation and teamwork. }\end{array}$ & $\begin{array}{l}0 \\
(0 \%)\end{array}$ & $\begin{array}{l}0 \\
(0 \%)\end{array}$ & $\begin{array}{l}0 \\
(0 \%)\end{array}$ & $\begin{array}{l}11 \\
(29.7 \%)\end{array}$ & $\begin{array}{l}26 \\
(70.3 \%)\end{array}$ & 4.70 & .46 \\
\hline $\begin{array}{l}\text { This project helped me broaden my horizons } \\
\text { and grow, and made me more mature. }\end{array}$ & $\begin{array}{l}0 \\
(0 \%) \\
\end{array}$ & $\begin{array}{l}0 \\
(0 \%) \\
\end{array}$ & $\begin{array}{l}4 \\
(10.8 \%) \\
\end{array}$ & $\begin{array}{l}10 \\
(27.0 \%) \\
\end{array}$ & $\begin{array}{l}23 \\
(62.2 \%) \\
\end{array}$ & 4.51 & .69 \\
\hline $\begin{array}{l}\text { This project inspired me to contribute my } \\
\text { professional knowledge and passion. }\end{array}$ & $\begin{array}{l}0 \\
(0 \%)\end{array}$ & $\begin{array}{l}0 \\
(0 \%)\end{array}$ & $\begin{array}{l}4 \\
(10.8 \%) \\
\end{array}$ & $\begin{array}{l}11 \\
(29.7 \%) \\
\end{array}$ & $\begin{array}{l}22 \\
(59.5 \%) \\
\end{array}$ & 4.49 & .69 \\
\hline $\begin{array}{l}\text { This project helped me understand issues of } \\
\text { social concern, such as parent-child } \\
\text { interaction, and parenting education. }\end{array}$ & $\begin{array}{l}0 \\
(0 \%)\end{array}$ & $\begin{array}{l}0 \\
(0 \%)\end{array}$ & $\begin{array}{l}1 \\
(2.7 \%)\end{array}$ & $\begin{array}{l}15 \\
(40.5 \%)\end{array}$ & $\begin{array}{l}21 \\
(56.8 \%)\end{array}$ & 4.54 & .55 \\
\hline $\begin{array}{l}\text { This professional service learning has } \\
\text { sparked my interest in participating in social } \\
\text { care and service activities. }\end{array}$ & $\begin{array}{l}0 \\
(0 \%)\end{array}$ & $\begin{array}{l}0 \\
(0 \%)\end{array}$ & $\begin{array}{l}2 \\
(5.4 \%)\end{array}$ & $\begin{array}{l}13 \\
(35.1 \%)\end{array}$ & $\begin{array}{l}22 \\
(59.5 \%)\end{array}$ & 4.54 & .60 \\
\hline
\end{tabular}

From Table 2 we know that most of the students $(45.9 \%+48.6 \%=94.5 \%)$ were satisfied with the content of the service learning project. And all of them $(43.2 \%+56.8 \%=100 \%)$ agreed or strongly agreed that they felt a sense of accomplishment and confidence while helping others with their profession. Moreover, most of them agreed or strongly agreed that this service learning project helped them increase their professional interest and motivation for the course $(37.8 \%+51.4 \%=89.2 \%, \mathrm{M}=4.38)$. The students did the activity through teamwork, and all students strongly agreed $(70.3 \%)$ or agreed $(29.7 \%)$ that this project helped them understand the spirit of cooperation and teamwork.

As for questions 5 and 6 , although most students chose agree or strongly agree, $11 \%$ of them chose neutral. The reason may be because just one activity was not enough for some students to feel that the project could help them broaden their horizons and grow, and make them more mature. The same reason applies to question 6 . In addition, $97 \%$ of the students agreed or strongly agreed that his project helped them understand issues of social concern, such as parent-child interaction, and parenting education. And $95 \%$ of them agreed or strongly agreed that this professional service learning had sparked their interest in participating in social care and service activities.

\subsubsection{The Questionnaire for the Parents}

Questionnaires were collected from 34 parents who joined the activity with their children. From the 34 subjects, six $(17.6 \%)$ were men and $28(82.4 \%)$ were women. This questionnaire was also designed using a 5-point Likert scale (with $1=$ strongly disagree, $2=$ disagree, $3=$ neutral, $4=$ agree, and $5=$ strongly agree). The responses are shown in Table 3. 
Table 3. Questionnaire for parents

\begin{tabular}{|c|c|c|c|c|c|c|c|}
\hline Question & 1 & 2 & 3 & 4 & 5 & $\mathbf{M}$ & SD \\
\hline $\begin{array}{l}\text { I think the timing of this event is } \\
\text { appropriate. }\end{array}$ & $\begin{array}{l}0 \\
(0 \%)\end{array}$ & $\begin{array}{l}0 \\
(0 \%)\end{array}$ & $\begin{array}{l}0 \\
(0 \%)\end{array}$ & $\begin{array}{l}9 \\
(26.5 \%)\end{array}$ & $\begin{array}{l}25 \\
(73.5 \%)\end{array}$ & 4.74 & .44 \\
\hline $\begin{array}{l}\text { I think the venue of this event is } \\
\text { properly arranged. }\end{array}$ & $\begin{array}{l}0 \\
(0 \%)\end{array}$ & $\begin{array}{l}0 \\
(0 \%)\end{array}$ & $\begin{array}{l}0 \\
(0 \%)\end{array}$ & $8(23.5 \%)$ & $\begin{array}{l}26 \\
(76.5 \%)\end{array}$ & 4.76 & .43 \\
\hline $\begin{array}{l}\text { I am satisfied with the content of this } \\
\text { event. }\end{array}$ & $\begin{array}{l}0 \\
(0 \%)\end{array}$ & $\begin{array}{l}0 \\
(0 \%)\end{array}$ & $\begin{array}{l}2 \\
(5.9 \%) \\
\end{array}$ & $\begin{array}{l}6 \\
(17.6 \%) \\
\end{array}$ & $\begin{array}{l}26 \\
(76.5 \%)\end{array}$ & 4.71 & .57 \\
\hline I think this activity meets my needs. & $\begin{array}{l}0 \\
(0 \%) \\
\end{array}$ & $\begin{array}{l}0 \\
(0 \%) \\
\end{array}$ & $\begin{array}{l}2 \\
(5.9 \%) \\
\end{array}$ & $\begin{array}{l}7 \\
(20.6 \%) \\
\end{array}$ & $\begin{array}{l}25 \\
(73.5 \%)\end{array}$ & 4.68 & .58 \\
\hline This event has positively helped me. & $\begin{array}{l}0 \\
(0 \%)\end{array}$ & $\begin{array}{l}0 \\
(0 \%)\end{array}$ & $\begin{array}{l}2 \\
(5.9 \%)\end{array}$ & $\begin{array}{l}6 \\
(17.6 \%)\end{array}$ & $\begin{array}{l}26 \\
(76.5 \%)\end{array}$ & 4.65 & .77 \\
\hline $\begin{array}{l}\text { If you hold a similar event, I will be } \\
\text { willing to participate again. }\end{array}$ & $\begin{array}{l}0 \\
(0 \%)\end{array}$ & $\begin{array}{l}0 \\
(0 \%)\end{array}$ & $\begin{array}{l}1 \\
(2.9 \%)\end{array}$ & $\begin{array}{l}6 \\
(17.6 \%) \\
\end{array}$ & $\begin{array}{l}27 \\
(79.4 \%)\end{array}$ & 4.74 & .61 \\
\hline $\begin{array}{l}\text { I am willing to recommend this event } \\
\text { to my friends. }\end{array}$ & $\begin{array}{l}0 \\
(0 \%)\end{array}$ & $\begin{array}{l}0 \\
(0 \%)\end{array}$ & $\begin{array}{l}1 \\
(2.7 \%)\end{array}$ & $\begin{array}{l}9 \\
(26.5 \%)\end{array}$ & $\begin{array}{l}24 \\
(70.6 \%)\end{array}$ & 4.65 & .64 \\
\hline
\end{tabular}

The activity was held on a Saturday afternoon. All of the parents agreed or strongly agreed that the timing was appropriate $(26.5 \%+73.5 \%=100 \%, \mathrm{M}=4.74)$, and all thought that the venuewas properly arranged (agree $23.5 \%$ + strongly agree $73.5 \%=100 \%, \quad M=4.76)$. Most were satisfied with the content of this event $(17.6 \%+76.5 \%=94.1 \%, M=4.71)$. On the questions of whether this activity met parents' needs and whether this event was helpful for them, the answers were positive, with $M=4.68$ and $M=4.65$. Therefore, on the questions of whether they would be willing to participate in a similar event again $(\mathrm{M}=4.74)$ and whether they were willing to recommend this event to their friends $((\mathrm{M}=4.65)$, most of them chose agree or strongly agree. From the data above we know that parents were satisfied with our service-learning activity.

\subsection{Qualitative Data Analysis}

\subsubsection{Qualitative Data of Undergraduate Students}

The qualitative data of undergraduate students were gathered from a questionnaire (QS), reflection paper (RF) and report (RP) filled out by the students on how they felt about the activity. The researcher analyzed students' writing on five different aspects:

(1) Enhancing the student's academic knowledge and skills

(2) Learning public service from the activity

(3) Cooperation and teamwork

(4) Benefits for children

(5) Suggestions of students after the activity

\section{Enhancing student's academic knowledge and skills}

Although some of our undergraduate students were working or had been worked as kindergarten teachers, most children in this activity were younger than the children they taught at kindergarten. The experience at this activity was thus different from what their work in kindergarten. This service-learning provided our undergraduate students a chance to put what they had learned at university into practice, and gave them a chance to teach young children. It provided our students a chance to help other people and had a positive impact on students' academic learning. Some students said:

\section{"This activity let me put what I have learned about activity design into practice." (RP40)}

"This event has helped me understand how to improve children's fine motor skills and gross motor ability.

This will be helpful for my teaching in the future." (QS15)

One student said this service-learning gave her a chance to be in contact with different kinds of children. She said:

"I took a close look at many children. Some children are lively. When I asked the lively children how old they are, they answered right away. However, I find one third of the children are shy. I used different methods to try to talk with the shy children. Some of them would interact with me, but some would not. I 
found out that every child has a different temperament. This experience has helped me to think about how to teach different kinds of children." (QS11)

The children's age range in our service-learning activity was from age 0 to 6 . The range is quite wide. Therefore it was difficult for our students to design activity games. Nevertheless, some students said they learned more through this. They said:

"We learned how to adjust the difficulty of the activity according to the age of the children." (QS22)

"The service-learning let me know more about the ability of smaller children ."(QS1)

Many students mentioned that they learned practical experience from this event. The following are some examples of their responses:

"The activities of each group were rich in content! I learned many new games from different groups and learned about how to design games for different ages of children!" (QS9)

"Through service-learning I learned how to teach and guide younger children."(QS2)

"This activity has given us us practical experience and was different from what we have learned in textbooks. We can take this experience back to our workplace." (RF29)

\section{Learning public service from the activity}

Through this activity, our students also learned a lot about public service and saw what they had learned from this event from different points of view. They wrote in their questionnaires and reports:

"This service-learning increased my enthusiasm for participating in service activities. I also have a better understanding of how a public babycare center works." (QS8)

"In this activity, I learned how to communicate well with others, and how to react spontaneously and quickly to meet the needs of different parents. This event increased my coping ability. I learned not only the skills of event design but also about interactions between people." (RF33)

"From this service learning, I learned that it brings you a lot of joy when you help others. And I also learned many interesting games, as well as how to interact with children." (RF40)

Students felt their efforts were worthwhile and their games were fun. And they felt their service-learning was meaningful:

"When I saw the interaction between parents and children, I was very excited. Our classmates really put a lot of effort, time, and energy into preparing this event. Every game that my classmates did was full of fun. Parents, young children and our team members all had a good time." (QS10)

"Through participating in the parent-child activities, I saw the interaction between parents and children. Our group were so happy to see that we used games to enhance parent-child interaction. When I saw their smiles during the games, I felt our service-learning activity was meaningful."(RP14)

"I have never taken the initiative to do something meaningful. After joining this event, I learned a lot. I saw our classmates carefully guiding and helping parents and children. I feel great. I hope that in the future, I can do something useful for the people around me. "(RF15)

\section{Cooperation and teamwork}

From open-ended questions in the questionnaire (QS), reflection form? (RF) and report (RP) of the students, we can see that many students described the importance of their experience with this service-learning event. Some students said that cooperating with the team members not only enhanced the friendship between the classmates, but also increased their professional learning ability (QS37, QS22, QS16). In addition, some students wrote in their reports:

"From preparation to completion of the activity, I could see that each member in our team worked hard to cooperate with each other to solve all problems." (RP29)

"During this event, our group forgot to bring our posters. We quickly borrowed color pens from the childcare center and worked together to make a new poster. In the process, we did not quarrel or blame anyone for the mistakes; instead, we worked together to solve the problem together. I learned a lot from this activity" (QS26).

"In the process of service learning, I learned how to cooperate with my classmates. Our classmates not only helped each other within their own group, they also helped classmates in other groups. Through that, 
they even gave suggestions to the other groups to help them solve problems. Some students have rich practical experience, and some students have more thoughtful thoughts. Everyone utilized their strengths to make the event go smoothly. I learned many things from my classmates through service learning." (RF31)

"While serving others, I am grateful and feel fulfilled. I feel that everyone in our class has done their part of the job well, so we made this event very vivid and effective. In retrospect, I feel that it was cooperation that made this service-learning so successful." (RP40)

\section{Benefits for children}

Our students also felt that this activity helped children increase their confidence. They wrote:

"Some of the games were challenging for young children, so parents and our gatekeepers had to constantly encourage children, build their confidence, and enhance their interaction with others." (RF40)

"In the activity, young children completed their activities independently, and there were activities that children had to work on together with their parents. From the activity, I saw that children felt self-confidence when they completed the activity independently" (QS11).

\section{Suggestions of students after the activity}

Our students saw other groups' games and wanted to have a try. But not until the end of the activity did they have a chance to play other groups' games. Therefore one student suggested that we could "leave some time for them to try all groups' games, to let them experience the content of the games" (QS15). Our students also gave some other suggestions after the event. Their suggestions included time, space, and the design of the games:

"Tables and chairs were insufficient." (QS2)

"Time of the activity can be shortened a bit because it was too long." (QS3).

"The space for our game was too small." (QS5).

"Very fun, we were able to learn great activities from practice, and I suggest that we can do more in the future." (QS36)

"This service-learning activity was fun. We can do it more than a few times in the future."(QS8).

"During this event, I found that our jigsaw puzzles were too difficult for some children. For children around 4 or 6, it is adjustable. But for children younger than 4, it's really too difficult. We think that we can improve the puzzle by cutting it in a simple way to make it easier for children to play. Watching the children happily playing our game, I felt that all our efforts were worth it." (RP23)

The students had fun with the activity and wanted to play the games themselves, therefore they suggested that:

"At the end of the event, we could be allowed to take turns to play the games from every other group and to experience how fun the game is." (QS15)

\subsubsection{Qualitative data of parents}

One open-ended question on the parent's questionnaire was: "What suggestions for or impressions of this event do you have?" One mother said that she learned about how many children play, and she felt that it was great (QP24). Two mothers said that they felt the activity was fun and they felt happy (QP2 and QP25). One parent suggested that the picture of the puzzle could be improved to make it clearer (QP23). One father wrote on the questionnaire that he was grateful for the daycare center holding this activity for the children and the activity was beneficial for the children (QP14). All comments and suggestions from the parents were positive.

\section{Conclusion}

The findings of this research demonstrated that this service learning experience was beneficial for children, parents and the students, enhancing student's academic knowledge, problem solving skills, and interpersonal development (friendship between classmates through teamwork).

Both our quantitative and qualitative data showed that both our students and parents felt that this service-learning was beneficial, and they were satisfied with it. Our students perceived this service-learning as a positive experience and found this experience to be helpful for their work in the future.

The results of this project were consistent with the results of most outcomes in the literature: students reported positive experience with service-learning and growth as individuals, they gained respect for their peers, and learned things that they never could from a textbook (Kasitz, 2009, Roofe, 2012). The research of Roofe (2012) about the "impact of service-learning on undergraduate dietetics education" showed beneficial outcomes for the 
students who participated in the service-learning program as well as for the research recipients (kindergarten children and parents). The outcomes of my research are consistent with hers.

Service-learning provides benefits for both groups - those providing the service and those receiving the service. In this study, the university benefited by developing a relationship with a childcare center that provided practical experience for the students. The childcare center thanked our students for their help with the activity and invited us to join them in a similar activity again the next year. The children and parents also benefited from the activity.

\section{References}

A Brief History of Service-Learning (2017). Retrieved from https://dornsife.usc.edu/joint-educational-project/service-learning-theory/

Bandy, J. (2017). What is Service Learning or Community Engagement? Retrieved from https://cft.vanderbilt.edu/guides-sub-pages/teaching-through-community-engagement/

Brown, J. M., \& Schmidt, N. A. (2016). Service-learning in undergraduate nursing education: Where is the reflection? Journal of Professional Nursing, 32(1), 48-53. https://doi.org/10.1016/j.profnurs.2015.05.001

Celio, C. I., Durlak, J., \& Dymnicki, A. (2011). A meta-analysis of the impact of service-learning on students. Journal of Experiential Education, 34, 164-181. https://doi.org/10.1177/105382591103400205

Chang, P. Y. (2012). Professional service-learning of college students with majors in child care and education at kindergartens and nursery Schools. Minghsin Journal, 38(1), 163-187. https://doi.org/10.29688/MHJ.201202.0012

Chang, C.-W., \& Chen, L.-C. (2014). Study of Teacher Educational Service Learning. Minghsin Journal, 40(1), 273-288.

Chen, L.-C. (2015). An action research on applying service-learning in teaching visual arts course of department of child development and education. Research in Arts Education, 29, 125-145.

Conway, J. M., Amel, E. L., \& Gerwien, D. P. (2009). Teaching and learning in the social context: A meta-analysis of service learning's effects on academic, personal, social, and citizenship outcomes. Teaching of Psychology, 36, 233-245. https://doi.org/10.1080/00986280903172969

Eyler, J., Giles, D. E., Stenson, C. M., \& Gray, C. J. (2001). At-a-glance: What we know about the effects of service-learning on students, faculty, institutions, and communities, 1993-2001. Retrieved from https://www.mnsu.edu/cetl/academicservicelearning/Service-Learning.pdf

Hsu, P.-C. (2012). The realization of educational ideas and practice of college students participating in reading-guidance program in service-learning curriculum for the disadvantaged children. Journal of Early Childhood Education, 23, 45-67.

Kasitz, D. L. H. (2009). From the Classroom to the Community-Designing a_Service-Learning Course in Political Science. Paper presented at the Southern political science association.

K-12 Service-Learning Standards for Quality Practice. (2017). Retrieved from https://nylc.org/standards/

Lake, V. E., \& Jones, I (2008). Service-learning in early childhood teacher education: Using service to put meaning back into learning. Teaching and Teacher Education, 24(8), 2146-2156. https://doi.org/10.1016/j.tate.2008.05.003

Lin, C.-Y., Wu, S.-W., Wu, S.-F., Pan, B.-S., \& Liao, H.-C. (2013). Effects of service-learning in a University in Taiwan. 5th World Conference on Educational Sciences - WCES 2013. Procedia - Social and Behavioral Sciences, 116, 902-906.

National Youth Leadership Council. (2017). What is service-learning? Retrieved from https://nylc.org/service-learning/

Roofe, N. L. (2012). Impact of service-searning on undergraduate dietetics education. Journal of Family and Consumer Sciences, 104(4), 28-33.

Sy, B. M. (2011, June). Touching hearts through service learning: The Taiwan experience. Paper presented at the 3rd Asia-Pacific Regional Conference on Service-Learning: Theory and Practice of Service-Learning: Cross-Cultural Service-Learning Programme in Asia-Pacific Region, Hong Kong. 


\section{Copyrights}

Copyright for this article is retained by the author(s), with first publication rights granted to the journal.

This is an open-access article distributed under the terms and conditions of the Creative Commons Attribution license (http://creativecommons.org/licenses/by/4.0/). 